\title{
DECOLORIZATION OF AZO DYES AND MINERALIZATION OF PHENANTHRENE BY TRAMETES SP. AS03 ISOLATED FROM INDONESIAN MANGROVE FOREST
}

\author{
Asep Hidayat ${ }^{1 *}$ and Sanro Tachibana ${ }^{2}$ \\ Received: 23 October 2013, Accepted: 17 March 2014
}

\begin{abstract}
Textile industry contributes the most disposals of synthetic dyes, and about $40 \%$ of textile dyes has been generating high amount of colored wastewater. Polycyclic aromatic hydrocarbons (PAHs), such as phenanthrene, is a group of organic compounds, that structurally comprised of two or more benzene rings, which persist in air, water, and soil. The organic pollutants of dyes and PAHs have adversely effects the food chain and are potentially toxic, mutagenic, and carcinogenic to the environment. The objective of this research is to screen and investigate the potential fungus from mangrove forest to degrade azo dyes and phenanthrene. In this study, fungi were collected from mangrove forest in Riau Province Sumatra - Indonesia. Previously, Trametes sp. AS03 is one of the fungi isolated from mangrove forest in Riau Province, that was able to decolorize Remazol Brilliant Blue R (RBBR). The capability of Trametes sp. AS03 to decolorize four azo dyes, Remazol B. Violet (V5), Levafix Orange E3GA (Or64), Levafix B. Red E-6BA (R159), and Sumifix S. Scarlet 2GF (R222), were further evaluated. The result shows that Trametes sp. AS03 decolorized 91, 60, 48, and 31 of V5, R222, R159, and Or64, respectively. By showing its capability to decolorize some of the dyes, Trametes sp. AS03 was used to break down phenanthrene. AS03 degraded more than $70 \%$ of phenanthrene in 15 days.
\end{abstract}

Keywords: Trametes sp. AS03, dyes, phenanthrene, biodegradation, decolorization

\begin{abstract}
ABSTRAK
Sekitar $40 \%$ zat pewarna tekstil telah menyebabkan pencemaran pada air buangan. Polycyclic aromatic bydrocarbons (PAHs), seperti phenanthrene, adalah kelompok senyawa organik yang memiliki dua atau lebih cincin benzena dan keberadaanya sangat sulit terurai baik yang berada di udara, air dan tanah. Organik polutan seperti zat pewarna dan PAHs mempunyai efek negatif terhadap rantai makanan, dan berpotensi untuk menjadi toksik, mutagenik, karsinogenik di lingkungan. Penelitian ini bertujuan untuk melakukan skrening dan mengevaluasi potensi jamur yang berasal dari hutan mangrove sebagai agen pengurai zat pewarna dan phenanthrene. Dalam penelitian ini, tubuh buah jamur dikumpulkan dari Hutan Mangrove di Provinsi Riau-Indonesia. Jamur Trametes sp. AS03 berhasil diisolasi dan memiliki kemampuan untuk mengurai zat pewarna Remazol Brilliant Blue R (RBBR). Kemampuan Trametes sp. AS03 untuk mengurai empat (4) tipe zat pewarna, Remazol B. Violet (V5), Levafix Orange E3GA (Or64), Levafix B. Red E-6BA (R159), dan Sumifix S. Scarlet 2GF (R222), dievaluasi dalam penelitian ini. Hasilnya menunjukkan bahwa Trametes sp. AS03 mampu mendegradasi 91, 60, 48, dan 31\% masing-masing untuk V5, R222, R159, and Or64 selama 3 hari masa inkubasi. Dari kemampuannya ini, Trametes sp. AS03 juga dicobakan untuk mengurai phenanthrene. Jamur AS03 mampu mendegradasi lebih dari 70\% phenanthrene selama 15 hari masa inkubasi.
\end{abstract}

Kata kunci: Trametes sp. AS03, zat pewarna, phenanthrene, biodegradasi, pengurai warna

\footnotetext{
${ }^{1}$ Research Institute on Fiber Technology of Plantation Forest, Jl. Raya Bangkinang Kuok Km. 9, Bangkinang, Riau 28294 Indonesia

${ }^{2}$ Department of Applied Bioscience, Faculty of Agriculture, Ehime University 3-5-7 Tarumi, Matsuyama, Ehime, $790-8566$-Japan

*Corresponding Author: ashephidayat@yahoo.com
} 


\section{INTRODUCTION}

Colored substances are called a dye and widely used in many industries including paper printing, food, color photography, textile dyeing, pharmaceutical, paintings and other fields to support human daily-life. Among the different industries, the textile industry contributes the most disposal of synthetic dyes, from 10,000 different dyes for a production of about 700,000 tons/year (Zongllinger, 1991), and about $40 \%$ of textile dyes generated higher colored wastewater and it is a significant source of water pollution in the environment (Jin et al., 2007). It could be understood because the discharge of a little amount of dyes $(<1 \mathrm{ppm})$ in water can absorb light penetration and may impedes the growth of microorganism, has adverse effect on food chain and to treatment processes (Ciullini et al., 2008). Azo dyes have been widely used in textile processing and are dominating, contributing about $70 \%$ of dyestuffs on the worldwide market. Azo dyes and their substitutions are highly resistant to degradation (Enayatzamir et al., 2009), toxic in their reductive metabolism product and potentially carcinogenic amine.

Phenanthrene is a polycyclic aromatic hydrocarbon (PAH) and structurally similar to azo dyes, it is composed of more than one benzene ring. Their major source is crude oil (Bamforth and Singleton, 2005; Passarini et al., 2011), and they are categorized as the prime environmental pollutants (Bamforth and Singleton, 2005). These compounds are highly hydrophobic (Cerniglia, 1992), and persist in air, water, and soil (Bamforth and Singleton, 2005). Degradation by microbial agent has been claimed to be a viable, relatively low cost, lowtechnology technique and publicly acceptable to more traditional physical-chemical methods, which are expensive, create disposal problem and have limited applicability (Erdogan and Karaca, 2011). The use of lignin-degrading white-rot fungi have increased more than the bacteria because these organisms are able to degrade various recalcitrant organic pollutants (Verdin et al., 2004; Mastubara et al., 2006). Their ligninolytic enzymes such as peroxidase and laccase-type enzymes are directly and indirectly involved in degradation processes (Cerniglia and Sutherland, 2001; Potin et al., 2004; Singh, 2006). Although, white-rot fungi have been able to degrade organic pollutants but it remains a big challenge in finding the fungi from mangrove forests for their ability to degrade azo dyes and phenanthrene. The objective of this study was to investigate the capability of fungus screened from mangrove forest in Riau Province - Indonesia to degrade azo dyes and phenanthrene.

\section{MATERIAL AND METHOD}

\section{A. Chemicals}

Remazol B. Violet (V5), Levafix Orange E3GA (Or64), Levafix B. Red E-6BA (R159), Sumifix S. Scarlet 2GF (R222) were obtained from Textile Company-Japan. Remazol Brilliant Blue R (RBBR) was purchased from Sigma (St. Louis, USA). The structure of all dyes is displayed in Figure 1. Phenanthrene and other chemicals were purchased from Wako Pure Chemical Industry (Osaka, Japan) at the highest available purity.

\section{B. Fungi and Culture Condition}

Fungi used in this study was isolated from decay wood pieces and fungal body collected from mangrove swamps of Sungai Pakning and Tanjung Buton - Riau province, Indonesia (1 19'58" N 102 9'16" and 0 58'4" N 102 15'2" E). They were maintained on malt extract agar (MEA) medium containing malt extract (20 $\left.\mathrm{g} \mathrm{L}^{-1}\right)$, glucose $\left(20 \mathrm{~g} \mathrm{~L}^{-1}\right)$, agar $\left(20 \mathrm{~g} \mathrm{~L}^{-1}\right)$, and polypeptone $\left(1 \mathrm{~g} \mathrm{~L}^{-1}\right)$ at $25^{\circ} \mathrm{C}$ for several days and maintained at $4^{\circ} \mathrm{C}$.

\section{Isolation and Identification of Fungi}

The sample was firstly screened for the ability to decolorize RBBR (100 mg L-1) in the Czapek-Dox agar medium containing of glucose $\left(10 \mathrm{~g} \mathrm{~L}^{-1}\right)$, saccharose $\left(10 \mathrm{~g} \mathrm{~L}^{-1}\right), \mathrm{KH}_{2} \mathrm{PO}_{4}(1 \mathrm{~g}$ $\left.\mathrm{L}^{-1}\right)$, KCL $\left(0.5 \mathrm{~g} \mathrm{~L}^{-1}\right), \mathrm{MgSO}_{4} 7 \mathrm{H}_{2} \mathrm{O}\left(0.5 \mathrm{~g} \mathrm{~L}^{-1}\right)$, $\mathrm{FeSO}_{4} 7 \mathrm{H}_{2} \mathrm{O}\left(0.01 \mathrm{~g} \mathrm{~L}^{-1}\right)$, Yeast extract $\left(2 \mathrm{~g} \mathrm{~L}^{-1}\right)$, polypeptone $\left(2 \mathrm{~g} \mathrm{~L}^{-1}\right)$ and agar $\left(15 \mathrm{~g} \mathrm{~L}^{-1}\right)$. The best fungus strain for each source was selected for further study.

DNA was extracted from cultured mycelia using a modified CTAB method (Murray and Thompson, 1980). The internal transcribed spacer ITS regions (Jellison and Jasalavich, 2000) was amplified by polymerase chain reaction (PCR) using the primers ITS1-F 
(5'-CTTGGTCATTTAGAGGAAGTAA-3') and ITS4-B (5'-CAGGAGACTTGTACAGGTCCAG-3'). The PCR was performed in $20 \mu \mathrm{l}$ of a solution containing $10 \mathrm{ng}$ of genomic DNA, 5 pmol each of the forward and reverse primer, and $10 \mu \mathrm{l}$ of Go Taq ${ }^{\circledR}$ Hot Start Colourless Master Mix (Promega, Wisconsin, USA) according to the manufacturer's instructions. Initial denaturation was performed at $95^{\circ} \mathrm{C}$ for $2 \mathrm{~min}$, followed by $30-35$ cycles of denaturation at $95^{\circ} \mathrm{C}$ for $0.5 \mathrm{~min}$, annealing at $55-72^{\circ} \mathrm{C}$, and polymerization at $72^{\circ} \mathrm{C}$ for $1 \mathrm{~min}$, and final extension at $72^{\circ} \mathrm{C}$ for $10 \mathrm{~min}$. Prior to sequencing, the PCR products were purified using rAPid Alkaline Phosphatase ${ }^{\mathrm{TM}}$ (Roche, Germany) and exonuclease I (New England Biolabs, Massachusetts, USA). The purified PCR products were sequenced and BLAST searched for ITS sequences in the GenBank database (http://www.ncbi.nlm.nih. gov/).

\section{Decolorization of Dyes by Whole Fungal Culture}

The decolorization of azo dyes was also evaluated in malt extract liquid medium (MEM) containing malt extract $\left(20 \mathrm{~g} \mathrm{~L}^{-1}\right)$, glucose $(20$ $\left.\mathrm{g} \mathrm{L}^{-1}\right)$, and polypeptone $\left(1 \mathrm{~g} \mathrm{~L}^{-1}\right)$. The medium was sterilized for $20 \mathrm{~min}$ at $121^{\circ} \mathrm{C}$. Three disks ( $5 \mathrm{~mm}$ diameter) of actively growing fungus on agar were added into each flask. Azo Dyes were contaminated after 7 days of fungi cultivation. $6 \mathrm{ml}$ samples were withdrawn and filtered at regular intervals. Using the remaining $6 \mathrm{ml}$, the supernatants were analyzed at the wavelength of maximum absorbance $\left(\lambda_{\max }\right)$ of each azo dyes solution using a UV-visible spectrophotometer. Percentage decolorization was calculated as:

$\%$ Decolorization $=((\mathrm{Ao}-\mathrm{At}) / \mathrm{At}) \times 100$

Where Ao and At are initial and final absorbance units, respectively (Couto, 2007).

\section{E. Degradation of Phenanthrene}

Degradation of phenanthrene was performed in 100-mL Erlenmeyer flasks containing $20 \mathrm{~mL}$ of liquid medium. The medium was sterilized for $20 \mathrm{~min}$ at $121^{\circ} \mathrm{C}$. Three disks (5mm diameter) of actively growing fungus on agar were added into each flask. The substrates, phenanthrene, dissolved in N,N' dimethylformamide (DMF), Tween80, and water) were added to each

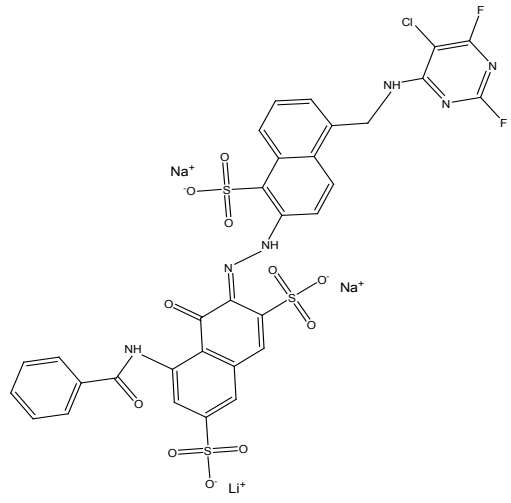

Levafix B. Red E-6BA

Reactive Red 159) - R159

No identified chemical structure Sumifix S. Scarlet 2GF - R222

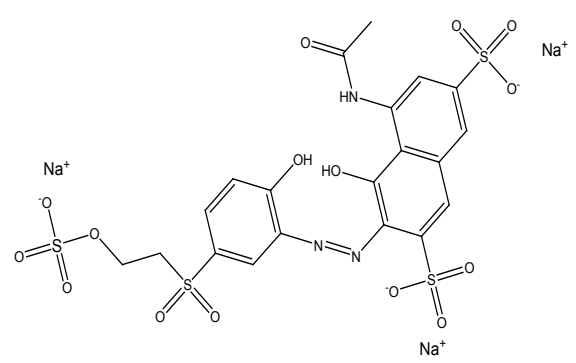

Remazol B. Violet (Reactive Violet 5) - V5

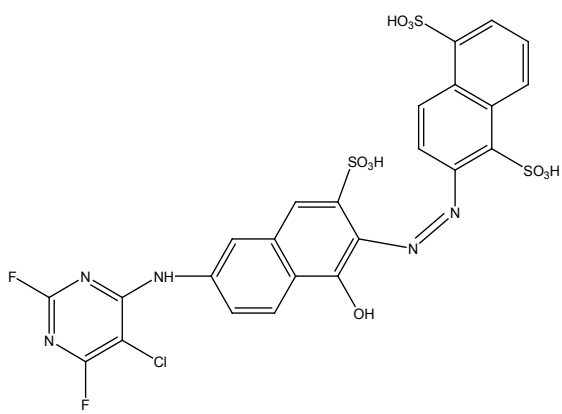

Levafix Orange E2GA

(Reactive Or64) - Or64

Figure 1. Structure of azo dyes 
culture and continuously incubated for 5, 10, and 15 days in the dark at $25^{\circ} \mathrm{C}$. The effects of various liquid cultures were investigated: 1 ) ME medium, 2) modified Kirk's medium containing glucose $\left(10 \mathrm{~g} \mathrm{~L}^{-1}\right)$, ammonium tartrate $(0.2 \mathrm{~g}$ $\left.\mathrm{L}^{-1}\right), \mathrm{KH}_{2} \mathrm{PO}_{4}\left(0.2 \mathrm{~g} \mathrm{~L}^{-1}\right), \mathrm{MgSO}_{4} 7 \mathrm{H}_{2} \mathrm{O}(50 \mathrm{mg}$ $\left.\mathrm{L}^{-1}\right), \mathrm{CaCl}_{2} 2 \mathrm{H}_{2} \mathrm{O}\left(10 \mathrm{mg} \mathrm{L}^{-1}\right)$, thiamine $(2 \mathrm{mg}$ $\left.\mathrm{L}^{-1}\right)$, and trace element $\left(10 \mathrm{~mL} \mathrm{~L}^{-1}\right)$ with a trace mineral solution consisting of $\mathrm{MgSO}_{4} 7 \mathrm{H}_{2} \mathrm{O}(3$ $\left.\mathrm{g} \mathrm{L}^{-1}\right), \mathrm{MnSO}_{4} 7 \mathrm{H} 2 \mathrm{O}\left(0.5 \mathrm{~g} \mathrm{~L}^{-1}\right), \mathrm{NaCl}^{4}\left(1 \mathrm{~g} \mathrm{~L}^{-1}\right)$, $\mathrm{FeSO}_{4} 7 \mathrm{H}_{2} \mathrm{O}\left(0.1 \mathrm{~g} \mathrm{~L}^{-1}\right), \mathrm{CoCl}_{2}\left(0.1 \mathrm{~g} \mathrm{~L}^{-1}\right), \mathrm{ZnSO}_{4}$ $7 \mathrm{H}_{2} \mathrm{O}\left(0.1 \mathrm{~g} \mathrm{~L}^{-1}\right), \mathrm{CuSO}_{4}\left(0.1 \mathrm{~g} \mathrm{~L}^{-1}\right), \mathrm{H}_{3} \mathrm{BO}_{3}(10$ $\left.\mathrm{mg} \mathrm{L}^{-1}\right)$, and $(\mathrm{Na})_{2} \mathrm{MoO}_{4} \mathrm{H}_{2} \mathrm{O}\left(10 \mathrm{mg} \mathrm{L}^{-1}\right)$, and 3) mineral salt broth (MSB) medium containing glucose $\left(10 \mathrm{~g} \mathrm{~L}^{-1}\right)$, ammonium tartrate $(0.2 \mathrm{~g}$ $\left.\mathrm{L}^{-1}\right), \mathrm{KH}_{2} \mathrm{PO}_{4}\left(2 \mathrm{~g} \mathrm{~L}^{-1}\right), \mathrm{MgSO}_{4} 7 \mathrm{H}_{2} \mathrm{O}\left(0.5 \mathrm{~g} \mathrm{~L}^{-1}\right)$, $\mathrm{CaCl}_{2} 2 \mathrm{H}_{2} \mathrm{O}\left(0.1 \mathrm{~g} \mathrm{~L}^{-1}\right)$, thiamine $\left(1 \mathrm{mg} \mathrm{L}^{-1}\right)$, and trace element $\left(10 \mathrm{~mL} \mathrm{~L}^{-1}\right)$ with the trace mineral solution consisting of $\mathrm{MnSO}_{4} 7 \mathrm{H} 2 \mathrm{O}\left(3 \mathrm{mg} \mathrm{L}^{-1}\right)$, $\mathrm{CoSO}_{4}\left(1 \mathrm{mg} \mathrm{L}^{-1}\right), \mathrm{FeSO}_{4} 7 \mathrm{H}_{2} \mathrm{O}\left(12 \mathrm{mg} \mathrm{L}^{-1}\right)$, $\mathrm{ZnSO}_{4} 7 \mathrm{H}_{2} \mathrm{O}\left(3 \mathrm{mg} \mathrm{L}^{-1}\right)$, and $\left(\mathrm{NH}_{4}\right)_{6} \mathrm{Mo}_{7} \mathrm{O}_{24}$ $4 \mathrm{H}_{2} \mathrm{O}\left(1 \mathrm{mg} \mathrm{L}^{-1}\right)$ (Tien and Krik, 1988; Arora and Gill, 2001; Hidayat et al., 2012).

All the experiments were conducted in triplicate. For the 5, 10, and 15 days cultures, the residual substrates were quantified by extracting three times with ethyl acetate in acidic conditions (5 $\mathrm{mL}$ of $1 \mathrm{~N} \mathrm{HCl}$ per-flask culture). The ethyl acetate extract was dried over anhydrous $\mathrm{Na}_{2} \mathrm{SO}_{4}$ and dry evaporated in a vacuum at $40^{\circ} \mathrm{C}$. The concentrate of extracts were quantified by gas chromatography (GC-FID Shimadzu 2014) with a TC-5 capillary column (length: $30 \mathrm{~m}$, inner diameter: $0.24 \mathrm{~mm}$ ). The carrier gas was helium delivered at a constant rate of $1.5 \mathrm{~mL} \mathrm{~min}^{-1}$ with a column pressure of $100 \mathrm{Kpa}$ and interface temperature of $280^{\circ} \mathrm{C}$. The temperature was started at $60^{\circ} \mathrm{C}$, and increased by $10^{\circ} \mathrm{C} \mathrm{min}^{-1}$ to $280^{\circ} \mathrm{C}$ where it was maintained for $10-20 \mathrm{~min}$ to allow late eluting compounds to exit the column (Hidayat and Tachibana, 2013).

\section{F. MnP and Laccases Assay}

The enzymatic activities were quantified directly after decolorization analysis (as mentioned in the section above). Activities of Manganese peroxidase $(\mathrm{MnP})$ and laccases were assayed spectrophotometrically. Manganese peroxidase $(\mathrm{MnP})$ activity was assayed using $50 \mathrm{mM}$ malonate buffer and dimethoxyphenol in $20 \mathrm{mM}$ of manganese sulfate $\left(\mathrm{MnSO}_{4}\right)$ at
$470 \mathrm{~nm}$ (Wariishi et al., 1992). Laccase activity was assayed by measuring the increase in absorbance at $525 \mathrm{~nm}$ using syringaldazine as a substrate in sodium acetate buffer (Leonowicz and Grzywnowics, 1981). All experiments were carried out at $25^{\circ} \mathrm{C}$. Activities were expressed as international units per liter of enzyme, where one unit of activity is defined as the amount of enzyme necessary to convert $1 \mu \mathrm{mol}$ of substrate in $1 \mathrm{~min}$.

\section{G. Data Analysis}

All results were presented as means \pm the standard deviation and analyzed using SPSS version 15 for windows. When necessary, results were also analyzed with Pearson correlation coefficients $(r)$, a two-tailed test of significance $(\mathrm{P}<0.05)$. The azo dyes decolorization data collected from pH 8.2 with saline condition was expressed with first-order kinetics (Ting et al., 2011) $: S=S_{0} \exp \left(-k_{1} t\right), t_{1 / 2}=\ln 2 / k_{1}$, where $\mathrm{S}_{0}$ is the initial concentration, $\mathrm{S}$ is the substrate concentration at time $t, t$ is the time period, and $\mathrm{k}_{1}$ is the decolorization rate constant.

\section{RESULT AND DISCUSSION}

\section{A. Isolation and Identification of Fungi}

A preliminary screening was performed using RBBR in agar medium, which has been used to identify fungi with the ability to break down various recalcitrant organic pollutants (Sato et al., 2003; Passarini et al., 2011). Among a total of 16 fruiting bodies of fungi collected, only 6 grew well, covering more than $70 \%$ of the Petri dish, and 1 isolate, named ASO3 caused a change in the color of RRBR (Figure. 2).

These isolates were selected for further study, because they showed higher decolorization of RBBR compared with other isolates. The 560bp ITS sequence (ITS1/5.8S) was compared with similar sequences in the GenBank database using the BLAST online search program. Alignments of the strains, both manually and using cluster $\mathrm{W}$, were conducted. Alignment of the strains showed that a partial sequence of AS03 had a maximum similarity index of 99\% relative to Trametes hirsuta (Accession No. JN048768, JX861099, and FJ891292) and so it was named as Trametes sp. AS03. 


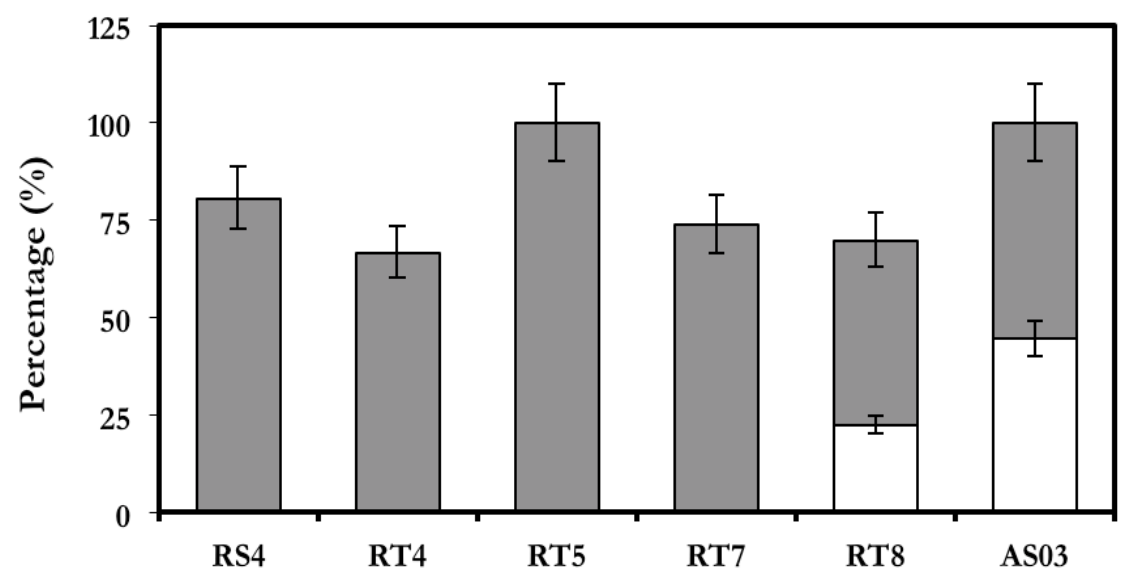

Figure 2. Growth of several isolated fungi in agar medium containing $100 \mathrm{mg} \mathrm{L}^{-1}$ of RBBR.

\section{Remarks :}

Observations were conducted on both the growth of fungi (grey bars) and the decolorization of RBBR (white bars) after 7 days incubation

\section{B. Decolorization of Some Azo Dyes}

Decolorization of some of the azo dyes was further evaluated in liquid medium. Figure 3 shows the decolorization of four types of azo dyes by AS03. The ability of AS03 to decolorize dyes was $91,48,31$ and $60 \%$ for V5, R159, Or64 and $\mathrm{R} 222$, respectively. The decolorization rate of four type of azo dyes was in the order of V5 $>\mathrm{R} 222>\mathrm{R} 159>\mathrm{Or} 64$ indicating that V5 is the most degradable azo dyes.

In alkaline condition, culture was adjusted to salinity $\left(35^{\circ} \%\right)$ by addition of artificial sea water and $\mathrm{pH}$ 8.2. $\mathrm{pH}$ is an important key in the azo dyes decolorization. Over 83, 42, 31 and 58\% of V5, R159, Or64 and R222 were decolorized by $\mathrm{AS} 03$ after 3 days incubation. Generally, the decolorization ability dropped less than $10 \%$ but this research result is an important finding because azo dyes decolorization by microorganisms in alkaline condition have been less studied, especially by fungi. The decolorization of dyes was greatly influenced by ligninolytic enzymes produced by fungi. In other hand, also $\mathrm{pH}$ was closely related to production of enzymes such as laccases and MnP. The contribution of the ligninolytic enzyme, laccase

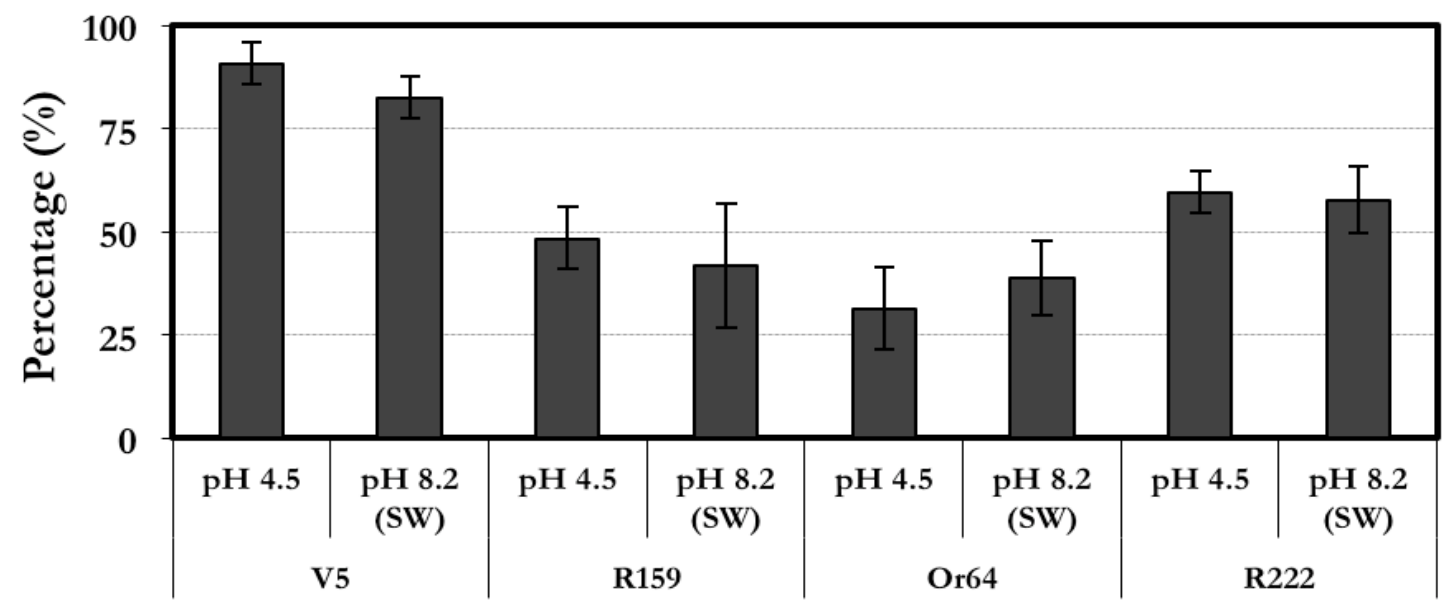

Figure 3. Decolorization of some of the azo dyes, Remazol B. Violet (V5), Levafix Orange E3GA (Or64), Levafix B. Red E-6BA (R159), Sumifix S. Scarlet 2GF (R222), by Trametes sp. AS03 in different $\mathrm{pH}$ and salinity (SW) after 3 days incubation 
Table 1. Effect of some azo dyes on decolorization rate constants, $\mathrm{MnP}$ and Lac activities in malt the extract liquid cultured under saline condition $(35 \mathrm{o} / \mathrm{oo})$.

\begin{tabular}{|c|c|c|c|c|c|c|c|c|c|c|c|}
\hline \multirow{4}{*}{ Fungi } & \multirow{4}{*}{ Pigments $^{a}$} & \multirow{4}{*}{$\mathrm{K}_{1}^{\mathrm{b}}$} & \multirow{4}{*}{$\mathrm{R}^{\mathrm{c}}$} & \multicolumn{8}{|c|}{ Enzyme activities $\left(\mathrm{U} \mathrm{L}^{-1}\right)$} \\
\hline & & & & \multicolumn{4}{|c|}{$\mathrm{MnP}$} & \multicolumn{4}{|c|}{$\mathrm{Lac}$} \\
\hline & & & & \multicolumn{3}{|c|}{ Incubation period } & \multirow[t]{2}{*}{$\mathrm{r}^{\mathrm{d}}$} & \multicolumn{3}{|c|}{$\begin{array}{c}\text { Incubation } \\
\text { period }\end{array}$} & \multirow{2}{*}{$\mathrm{r}^{\mathrm{d}}$} \\
\hline & & & & 1 & 2 & 3 & & 1 & 2 & 3 & \\
\hline \multirow[t]{4}{*}{ Trametes sp. (AS03) } & V5 & 0.62 & 0.93 & 3.86 & 5.32 & 7.19 & $0.83^{*}$ & 13.76 & 11.37 & 26.92 & $0.66 \mathrm{tn}$ \\
\hline & R159 & 0.15 & 0.64 & 0.93 & 1.73 & 2.66 & $0.84 *$ & 0.00 & 0.00 & 2.99 & $0.93^{* *}$ \\
\hline & Or64 & 0.17 & 0.82 & 0.67 & 1.20 & 2.66 & $0.90^{*}$ & 2.99 & 4.79 & 5.38 & $0.38 \mathrm{tn}$ \\
\hline & R222 & 0.30 & 0.94 & 1.06 & 2.00 & 2.66 & $1.00^{* *}$ & 0.00 & 2.99 & 3.59 & $1.00^{* *}$ \\
\hline
\end{tabular}

Remarks :

Degradation rate constants were calculated as described by Ting et al.(2011).

Correlation coefficients were determined between pigments and enzymes activities (MnP or Lac)

* Correlation is significant at the 0.05 level

** Correlation is significant at the 0.01 level

tn Correlation is not significant

a Initial pigment concentration is $100 \mathrm{mg} \mathrm{L}^{-1}$

and $\mathrm{MnP}$, to decolorization of azo dyes is crucial to evaluate, especially in saline condition.

The $\mathrm{MnP}$ and laccase enzymes activities were detected in liquid culture at saline condition ( $\mathrm{pH}$ 8.2), but varied greatly form one enzyme to another, type of azo dyes and time of incubation (Table 1). The azo dyes decolorization increased from 1 to 3 days incubation followed by increasing enzymes activities, both MnP and Laccase, in our experiments. The highest degradation was observed in the V5 azo dyes with decolorization rate constants $\left(\mathrm{k}_{1}\right)$ more than 0.62 per-days. The azo dyes decolorization correlated significantly with $\mathrm{MnP}$. The Laccase enzymes activities also correlated significantly for R159 and R222. The role of laccase and peroxidases secreted by fungi is controversial, which can be seen in this experiment. $\mathrm{MnP}$ is a major enzyme involved in this process, but laccases and $\mathrm{MnP}$ collaborated in these processes, although the laccases had the highest activities compared to MnP. Kalme et al., (2007) reported that degradation of azo dyes occurred if cleaved symmetrically and asymmetrically depending on the availability of enzymes. Although laccase and $\mathrm{MnP}$ are able to catalyst azo dyes, - breakdown azo bond and or cleavage between carbon of aromatic ring and nitrogen (Jadhav et al., 2011) -, but to make sure the degradation mechanism of each azo dyes used in this research is correct, some investigations need to be repeated in the future.

\section{Degradation of Phenanthrene}

Phenanthrene is considered to be a significant environmental pollutant due to their toxicity and mutagenicity (Bispo et al., 1999). The degradation of phenanthrene by Trametes sp. AS03 was investigated in three liquid mediums: ME, Kirk's and MSB. The time periods of degradation of AS03 are displayed in Table 2. The degradation of phenanthrene over 15 days in Kirk's medium was much higher $(72 \%)$ than that in ME (54\%) and MSB (50\%). Subsequently, metabolic studies were performed in Kirk's medium with phenanthrene as a substrate.

The mycelium biomass tends to increase with the incubation period for all mediums used (Table 2), but a high degradation rate was not associated with a high mycelium biomass. This indicates that the degradation of phenanthrene did not yield energy or carbon for fungal growth and the degradation occurred via intracellular detoxification (e.g. oxidation and hydroxylation), ring fission, and carbon assimilation (Cerniglia, 1984; Johnsen et al., 2005). Furthermore, the level of laccase activity was $273 \mathrm{U} \mathrm{L}^{-1}$ in modified Kirk's medium with phenanthrene, while the level of $\mathrm{MnP}$ activity was $53 \mathrm{U} \mathrm{L}^{-1}$. The enzymes activity levels were higher than in other types of medium, explaining why the degradation of phenanthrene was greater in modified Kirk's medium. The results also indicate that degradation of phenanthrene were truly associated with production of ligninolytic 
Table 2. The effect of various liquid cultures on degradation of phenanthrene, mycelium biomass and enzymatic activities of AS03

\begin{tabular}{crrrrrrrrr}
\hline \multirow{2}{*}{ Medium } & \multicolumn{3}{c}{ Degradation (\%) and weight mycelium biomass $(\mathrm{mg})^{*}$} & \multicolumn{4}{c}{ Enzymes activities $\left(\mathrm{U} \mathrm{L} \mathrm{L}^{-1}\right)$} \\
\cline { 2 - 10 } & \multicolumn{2}{c}{5 days } & \multicolumn{2}{c}{10 days } & \multicolumn{1}{c}{15 days } & Lac & MnP & Lip \\
\hline ME & 29.5 & $(98)$ & 35.4 & $(110)$ & 53.7 & $(133)$ & 235.8 & 44.8 & 11.5 \\
Modified Kirks & 14.6 & $(58)$ & 34.7 & $(83)$ & 71.7 & $(90)$ & 272.5 & 53.5 & nd \\
MSB & 17.5 & $(35)$ & 28.8 & $(49)$ & 50.4 & $(66)$ & nd & 0.8 & 2.8 \\
\hline
\end{tabular}

Remarks :

* Values in parentheses are mycelium biomass of fungus (mg)

$\mathrm{ME}=$ Malt extract liquid medium, $\mathrm{pH} 4.5$

Kirk's = Kirk's liquid medium, $\mathrm{pH} 4.5$

MSB $=$ Mineral salt medium, $\mathrm{pH} 4.5$

n.d $=$ not detected

enzymes, laccase and MnP (Ting et al., 2011). Modified Kirk's medium is a suitable medium for fungi to enhance production of enzymes as well as the highest degradation was obtained with this medium. The production of enzymes by white-rot fungi is affected by the limitation of nitrogen concentration in medium and is not altered by the presence of phenanthrene (Kaushik and Malik, 2009). The initial step degradation of phenanthrene by ligninolytic fungi is often catalyzed by intracellular P-450 monooxygenase to produce dihydrodiol and extracellular peroxidase and laccase to produce quinone (Bamforth and Singleton, 2005).

\section{CONCLUSION}

In this study, we demonstrated the ability of Trametes sp. AS03, a white-rot fungus collected from an Indonesian mangrove forest, to decolorize azo dyes and degraded phenanthrene. Trametes sp. AS03 decolorized 91, 60, 48, and 31 of V5, R222, R159, and Or64, respectively. The role of enzymes laccase and peroxidases secreted by AS03 in decolorization are still controversial, because $\mathrm{MnP}$ is a major enzyme in decolorization but laccases had the highest activities in comparison with $\mathrm{MnP}$. Phenanthrene was degraded about $72 \%$ after 15 days incubation, and degradation processes was associated with a combination of nonligninolytic and ligninolytic enzymes. Some investigations need to be repeated in the future regarding degradation mechanism of azo dyes and phenanthrene by AS03.

\section{ACKNOWLEDGEMENT}

The authors are grateful to Prof. Ko Harada, Department of Bioresource Production Science, Faculty of Agriculture, Ehime University, on the DNA identification of fungi and to our colleagues for critical reading and suggestions to improve the manuscript.

\section{REFERENCES}

Arora, D. S., \& Gill, P. K. (2001). Comparison of two assay procedures for lignin peroxidase. Ensyme Microbial Technology, 28, 602-605.

Bamforth, S. M., \& Singleton, I. (2005). Bioremediation of polycyclic aromatic hydrocarbon: current knowledge and future directions. Journal of Chemical Technology and Biotechnology, 80, 723-736.

Bispo, A., Jourdain, M. J., \& Jauzein, M. (1999). Toxicity and genotoxicity of industrial soils polluted by polycyclic aromatic hydrocarbons (PAHs). Organic Geochemistry, 30, 947-952.

Cerniglia, C. (1984). Microbial metabolism of polycyclic aromatic hydrocarbons. Advances in Applied Microbiology, 30, 31-71.

Cerniglia, C. E. (1992). Biodegradation of polycyclic aromatic hydrocarbons. Biodegradation, 3, 351368.

Cerniglia, C. E., \& Sutherland, J. B. (2001). Bioremediation of polycyclic aromatic hydrocarbons by ligninolytic and nonligninolytic fungi. In Fungi in bioremediation (Gadd, G.M., pp. 136-187). New York: Cambridge University Press. 
Ciullini, I., Tilli, S., Scozzafava, A., \& Briganti, F. (2008). Fungal laccase, cellobiose dehydrogenase, and chemical mediators: combined actions for the decolorization of different classes of textile dyes. Bioresource Technology, 99, 7003-710.

Couto, R. (2007). Decolouration of industrial azo dyes by crude laccase from Trametes hirsuta. Journal of Hazardous Materials, (148), 768-770.

Enayatzamir, K., Tabandeh, F., Yakhchali, B., Alikhani, H. A., \& Couto, S. R. (2009). Assessment of the joint effect of laccase and cellobiose dehydrogenase on the decoloration of different synthetic dyes. Journal of Hazardous Materials, 169, 176-181.

Erdogan, E. E., \& Karaca, A. (2011). Bioremediation of crude oil polluted soils. Asian Journal of Biotechnology, 3, 206-213.

Hidayat, A., \& Tachibana, S. (2013). Crude oil and n-octadecane degradation under saline conditions by Fusarium sp. F092. Journal of Environmental Sciences and Technology, 6, 29-40.

Hidayat, A., Tachibana, S., \& Itoh, K. (2012). . Determination of chrysene degradation under saline conditions by Fusarium sp. F092, a fungus screened from nature. Fungal Biology, 116, 706-714.

Jellison, J., \& Jasalavich, C. (2000). A review of selected methods for the detection of degradative fungi. International Biodeterioration \& Biodegradation, 46, 241-244.

Jin, X., Liu, G., Xu, Z., \& Yao, W. (2007). Decolorization of a dye industry effluent by Aspergillus fumigatus XC6. Applied Microbiology and Biotechnology, 74, 239-243.

Johnsen, A. R., Wick, L. Y., \& Harms, H. (2005). Principles of microbial PAH-degradation in soil. Environmental Pollution, 133, 71-84.

Kalme, S., Ghodake, G., \& Govindwar, S. (2007). RedHE7B degradation using desulfonation by Pseudomonas desmolyticum NCIM 2112. International Biodeterioration \& Biodegradation, 60, 327-333.

Kaushik, P., \& Malik, A. (2009). Fungal dye decolourization: Recent advances and future potential. Environment International, 35, 127141.

Leonowicz, A., \& Grzywnowicz, K. (1981). Quantitative estimation of laccase forms in some white-rot fungi using syringaldazine as a substrate. Ensyme and Microbial Technolog, 3, $55-58$.

Matsubara, M., Lynch, J. ., \& De Leij, F. A. A. M. (2006). No Title. Enzyme and Microbial Technology, 39, 1365-1372.

Murray, M. G., \& Thompson, W. F. (1980). Rapid isolation of high molecular weight plant DNA. Nucleic Acids Research, 8, 4321-4325.

Passarini, M. R. Z., Rodrigues, W. V. N., da Silva, M., \& Sette, L. D. (2011). Marinederived filamentous fungi and their potential application for polycyclic aromatic hydrocarbon bioremediation. Marine Pollution Bulletin, 62, 364-370.

Potin, O., Rafin, C., \& Veignie, E. (2004). Bioremediation of an aged polycyclic aromatic hydrocarbons (PAHs)-contaminated soil by filamentous fungi isolated from soil. International Biodeterioration \& Biodegradation, 54, $45-52$.

Jadhav, S.B., Swapnil, S. P., Pratibha, S. P., \& Jyoti, P. J. (2011). Biochemical degradation pathway of textile dye Remazol red and subsequent toxicological evaluation by cytotoxicity, genotoxicity and oxidative stress studies. International Biodeterioration \& Biodegradation, 65, 733-743.

Sato, A., Watanabe, T., Watanabe, Y., Harazono, K., \& Fukatsu, T. (2003). Screening for basidiomycetous fungi capable of degrading 2,7-dichlorodibenzo-p-dioxin. World Journal Microbiology and Biotechnology, 19, 763-766.

Singh, H. (2006). Mycoremediation: Fungal Bioremediation (pp. 115-148). New York, USA: John Wiley \& Sons.

Tien, M., \& Kirk, T. K. (1988). Lignin peroxidase of Phanerochaete chrysosporium. Methods Enzymol, 161, 238-249.

Ting, W. T. E., Yuan, S. Y., Wu, S. Y., \& Chang, B. V. (2011). Biodegradation of phenanthrene and pyrene by Ganoderma lucidum. International Biodeteriration \& Biodegradation, 65, 238-242.

Verdin, A., Sahraoui, A. L. H., \& Durand, R. (2004). Degradation of benzo[a]pyrene by mitosporic fungi and extracellular oxidative enzymes. International Biodeterioration \& Biodegradation, 35, 65-70.

Wariishi, H., Valli, K., \& Gold, M. H. (1992). Manganese (II) oxidation by manganese peroxidase from the basidiomycete Phanerochaete chrysosporium kinetic 
mechanism and role of chelators. The Journal of Biological Chemistry, 267, 23688-23695.

Zollinger, H. (1991). Colour chemistry: synthesis, properties and applications of organic dyes and pigments (5th ed., pp. 187-246). Weinheim: VCH Publishers. 